\title{
Pengaruh Gaya Kepemimpinan Kepala Sekolah Dan Profesionalisme Guru Terhadap Kinerja Guru Di SMP Negeri 1 Gondang Nganjuk
}

\author{
Siti Arifatun Nasrifah, ${ }^{1}$ Makhromi $^{2}$ \\ ${ }^{1}$ Pascasarjana Institut Agama Islam Tribakti Kediri, Institut Agama Islam Tribakti Kediri \\ ${ }^{1}$ arifatunnasrifah19@gmail.com, 2makhromighufta@gmail.com
}

\begin{abstract}
This study, taking the theme of the influence of the principal's leadership style and professionalism of teachers on teacher performance in SMP Negeri 1 Gondang, Nganjuk. Principal's leadership style and teacher professionalism are important indicators of achieving effective and efficient performance in an educational institution. This research approach is quantitative with ex post facto design. The population was all 60 Gondang 1 Junior High School teachers, then 42 samples were selected by using the Disproportionate Stratified random sampling technique. Data collection instrument in the form of a questionnaire with a Likert scale which has 4 alternative answers. The research instrument was tested on 42 teachers. The instrument validity test used was content validity with experimental judgment techniques, while for instrument reliability the Alpha Cronbach formula was used. Data analysis uses simple regression and multiple regression.The result is that the principal's leadership at SMPN 1 Gondang is included in the good category with an average score of 55,1429, professionalism of teachers in the professional category with an average score of 54.5714, the teacher's performance falls into the very good category with an average of 45.0714 . With a simple regression analysis it is known: there is no significant influence of the principal's leadership style on the performance of teachers of SMPN 1 Gondang because only -, 093, teacher professionalism does not affect the teacher's performance because it is only -, 102, but there is a positive and significant influence on the principal's leadership style on teacher professionalism that is equal to $98.3 \%$. The results of multiple regression analysis showed that there was a significant joint effect between the principal's leadership style and teacher professionalism on teacher performance at SMPN 1 Gondang, which was only $1.2 \%$.
\end{abstract}

Keywords: Leadership Style, Professionalism, Performance

Abstrak
Penelitian ini, mengambil tema pengaruh gaya kepemimpinan kepala sekolah
dan profisionalisme guru terhadap kinerja guru di SMP Negeri 1 Gondang,
Nganjuk. Gaya kepemimpinan kepala sekolah dan profesionalisme guru
merupakan indikator penting mencapi kinerja yang efektif dan efisian dalam
suatu lembaga pendidikan. Pendekatan penelitian ini adalah kuantitatif
dengan desain ex post facto. Populasi adalah seluruh guru SMPN 1 Gondang

Jurnal Intelektual: Jurnal Pendidikan dan Studi Keislaman

Volume 9, Nomor 3, Desember 2019 
yang berjumlah 60 orang guru kemudian diambil sampel sebanyak 42 guru yang dipilih dengan teknik Disproportionate Stratified random sampling. Instrumen pengumpulan data berupa kuesioner dengan skala likert yang memiliki 4 alternatif jawaban. Instrumen penelitian diujicobakan kepada 42 guru. Uji validitas instrumen yang digunakan adalah validitas isi dengan teknik eksperts judgment, sedangkan untuk reliabilitas instrumen menggunakan rumus Alpha Cronbach. Analisis data menggunakan regresi sederhana dan regresi berganda.Hasilnya adalah kepemimpinan kepala sekolah di SMPN 1 Gondang termasuk dalam kategori baik dengan skor ratarata 55.1429, profesionalisme guru dalam kategori profesional dengan skor rata-rata 54.5714, kinerja guru masuk dalam kategori sangat baik dengan ratarata 45.0714. Dengan analisis regresi sederhana diketahui: tidak terdapat pengaruh yang signifikan gaya kepemimpinan kepala sekolah terhadap kinerja guru SMPN 1 Gondang karena hanya -,093, profesionalisme guru tidak berpengaruh terhadap kinerja guru karena hanya -,102, namun terdapat pengaruh positif dan signifikan gaya kepemimpinan kepala sekolah terhadap profesionalisme guru yakni sebesar $98,3 \%$. Hasil anlisis regresi berganda menunjukkan ada pengaruh bersama-sama secara signifikan antara gaya kepemimpinan kepala sekolah dan profesionalisme guru terhadap kinerja guru di SMPN 1 Gondang yaitu hanya sebesar 1,2 \%.

Kata Kunci: Gaya Kepemimpinan, Profesionalisme, Kinerja

\section{Pendahuluan}

Pendidikan merupakan upaya manusia untuk memperluas cakrawala pengetahuannya dalam rangka membentuk nilai, sikap dan perilaku. Dalam era globalisasi saat ini semakin pesatnya perkembangan ilmu pengetahuan dan teknologi terutama teknologi informasi. Sehingga akan menuntut perubahan khususnya dalam dunia pendidikan. Kondisi tersebut menuntut kita untuk meningkatkan sumber daya manusia (SDM) yang berkualitas yang memiliki kemauan dan kemampuan untuk senantiasa meningkatkan kualitasnya secara terus menerus dan berkesinambungan. Pendidikan nasional bertugas dan bertanggung jawab untuk menyongsong dan mampu persaingan dengan adanya era globalisasi dan

Perubahan menjadi peluang dan kemudian dan mengelolanya menjadi kekuatan yang mampu meningkatkan kualitas hidup kehidupan bangsa dan Negara di masa depan. Pendidikan sebagai usaha sadar dan terencana, artinya dikehendaki, diinginkan, ada maksud dan tujuan baik secara eksplisit (nyata) maupun secara emplisit (terselubung) dari pihak pendidik. Pendidikan tidak terjadi secara kebetulan saja atau asal-asalan.

Kepemimpinan kepala sekolah memiliki gaya kepemimpinan yang strategis dalam mewujudkan keberhasilan penyelenggaraan dan pengelolaan pendidikan. Kepala sekolah adalah 
seorang manajer yang memegagang kekuasaan tertinggi dalam pengambilan keputusan yang berkaitan dengan penyelenggaraan dan pelaksanaan pendidikan di sekolah yang dipimpinnya. ${ }^{1}$

Kepala sekolah seharusnya seorang yang visioner yaitu mampu memandang kedepan tentang kehidupan masyarakat Indonesia dengan segala peluang dan tantangannya. Pendek kata kepala sekolah harus mampu memproyeksikan kemampuan dan kompetensi serta gaya kepemimpinan yang dperlukan bawahan dan masyarakat. Oleh karenanya dalam memimpin lembaga pendidikan kepala sekolah dituntut mampu menerapakan gaya-gaya kepemimpinannya yang dapat mencerminkan perilaku-perilaku yang dapat ditiru bawahannya dan dapat memberi motivasi kerja para guru dan staf yang dipimpinnya.

Baik atau buruknya mutu lulusan sekolah dari berbagai jenjang pendidikan juga dipengaruhi oleh berbagai komponen antara lain: organisasi dan manajemen, ketenagaan, ketatausahaan, sarana prasarana, program dan proses, lingkungan dan stakeholder. Mutu pendidikan maupun mutu sekolah sering tertuju kepada mutu lulusannya. Mutu lulusan yang rendah dapat menimbulkan berbagai masalah, seperti lulusan tidak dapat melanjutkan studi pada jenjang yang lebih tinggi, tidak dapat diterima di dunia kerja, diterima bekerja tapi tidak berprestasi, tidak dapat mengikuti perkembangan masyarakat, dan tidak produktif. Lulusan yang tidak, menambah biaya kehidupan, dan kemungkinan akan menjadi warga yang tersisih dari masyarakat. ${ }^{2}$

Proses pembelajaran yang bermutu dapat berlangsung dengan baik, bila siswa terlihat secara aktif, siswa memiliki motivasi belajar tinggi, siswa mempunyai minat dan perhatian dalam belajar, guru memperhatikan perbedaan individual siswa (prinsip individualitas), peragaan dalam pengajaran. Proses pembelajaran yang bermutu, siswa mempunyai hak dan kebebasan untuk bersuara, berpendapat dan berargumen di dalam kelas yang berkaiatan dengan materi pelajaran di kelas.

Sehubungan dengan tugas guru yang begitu penting dalam pencapaian mutu pendidikan, maka pemerintah telah melakukan usaha-usaha dalam rangka meningkatkan profesionalisme baik berupa peningkatan kompetensi maupun kesejahteraanguru. Kinerja adalah kemauan dan kemampuan seseorang dalam melakukan sesuatu pekerjaan. Bila guru mempunyai kinerja yang baik maka hasil proses belajar mengajar juga akan baik. Kinerja memegang peranan penting dalam pencapaian tujuan pengajaran yang optimal. Mengingat pentingnya kinerja ini maka sekolah perlu meningkatkan kinerja guru agar tujuan pengajaran dapat tercapai secara 
maksimal. Kinerja adalah suatu tampilan secara utuh atas perusahaan/organisasi selama periode waktu tertentu. ${ }^{3}$ Penilaian kinerja guru akan sangat membantu dalam upaya mengelola guru dan mengembangkannya dalam kerangaka mencapai tujuan pendidikan di sekolah. ${ }^{4}$ Sedarmayanti pun mengemukakan, penilaian kinerja adalah sistem formal untuk memeriksa/mengkaji dan mengevaluasi secara berkala kinerja seseorang. Kinerja dapat pula dipandang sebagai perpaduan: hasil kerja (apa yang harus dicapai oleh seseorang) dan kompetensi (bagaimana, seseorang mencapainya). ${ }^{5}$

Selanjutnya Supardi menyampaikan dari uraian dan deskripsi konsep mengenai kinerja, indikator kinerja, kinerja guru dan penilaian kinerja guru dapat dibuat sintesa teori, yang dimaksud dengan kinerja guru adalah kemampuan dan keberhasilan guru dalam melaksanakan tugas-tugas pembelajaran yang ditunjukan oleh indikator-indikator: (1) kemampuan menyusun rencana pembelajaran, (2) kemampuan melaksanakan pembelajaran, (3) kemampuan mengadakan hubungan antar pribadi, (4) kemampuan melaksanakan penilaian hasil belajar, (5) kemampuan melaksanakan pengayaan,

${ }^{3}$ Rivai dan Ella, Manajemen Sumber Daya Manusia untuk Perusahaan, (Jakarta: PT Raja Grafindo Persada, 2010), h. 604

4 Barnawi dan Arifin, Mohammad, Kinerja Guru Profesional, (Yogyakarta: Ar-Ruzz Media, 2012), h. 25 dan (6) kemampuan melaksanakan remedial. ${ }^{6}$

Masalah yang sering ditemui masih ada pada guru yang belum maksimal dalam menjalankan tugas, masih banyak guru yang belum mencerminkan guru yang professional dan memiliki kinerja yang baik, seperti belum membuat rencana pelaksanaan pembelajaran (RPP) yang merupakan landasan dalam pelaksanaan belajar mengajar, kurangnya kemahiran dalam mengelola kelas, selanjutnya adalah penguasaan materi yang belum maksimal dan ditambah dengan penggunaan metode mengajar yang tidak variatif dan penggunaan alat dan sumber belajar yang tidak bervariasi. $^{7}$

Oleh karena itu, sikap pendidikan seharusnya selalu mencerminkan peningkatan harkat dan martabat kemanusian untuk peningkatan kinerja masyarakat bangsa dan Negara

SMPN 1 Gondang adalah sekolah tingkat menengah pertama di kecamatan godang, yang menjadi tujuan utama bagi siswa yang melanjutkan sekolah di tingkat SMP. Jika mereka tidak lolos dalam seleksi penerimaan siswa baru di SMPN 1 Gondang, maka barulah mereka mencari pilihan ke sekolah lain.

Berdasarkan uraian latar berlakang di atas, penulis tertarik untuk meneliti di

pegawai negeri dan sipil, (Bandung: Refika Aditama, 2013), h. 261.

${ }^{6}$ Supardi, Kinerja Guru, (Jakarta: Raja Grafindo, 2014), h. 73

7 Mulyasa, Standar Kompetensi dan Sertifikasi Guru, (Bandung: Remaja Rosdakarya, 2012), h, 1-9 
tempat tersebut dan ingin mengungkap Pengaruh Gaya Kepemimpinan Kepala Sekolah dan Profesionalisme Guru terhadap Kinerja Guru di SMPN 1 Gondang Nganjuk.

\section{Metode}

Metode penilitian menurut Sugiono adalah metode yang berlandaskan pada filsafat positivme: metode yang digunakan untuk meneliti pada populasi atau sampel tertentu, teknik pengambilan sampel biasanya dilakukan dengan perhitungan teknik sampel tertentu yang sesuai. Pengumpulan data kuantitatif/ statistik dengan tujuan untuk menguji hipotesis yang telah ditetapkan. ${ }^{8}$

Penelitian ini mencari data empirik yang sistematik dan dalam penelitian ini peneliti tidak dapat mengontrol langsung variabel bebas karena peristiwanya telah terjadi dan menurut sifatnya tidak dapat dimanipulasi. Penelitian ini menempatkan pengaruh gaya kepemimpinan kepala sekolah dan profesionalisme guru terhadap kinerja guru di SMP Negeri 1 Gondang Nganjuk.

Target populasi dalam penelitian ini adalah guru di SMPN 1 Gondang Nganjuk, yang berjumlah 60 orang guru, yang terdiri dari 25 orang guru laki laki dan 35 orang guru perempuan. ${ }^{9}$ Sedangkan, berdasarkan Teknik pengambilan sampel Disproportionate Stratified Random Sampling jumlah

${ }^{8}$ Ruky, Ahmad S, Sistem Manajemen Kinerja, (Jakarta: Gramedia, 2001), h. 20-21

9 Sugiyono, Metode Penelitian Kuantitatif, Kualitatif dan RED, (Bandung: CV Alfabeta, 2010), h. 14 sampel dari populasi, dengan tingkat kepercayaan sebesar 5\%, maka peneliti mengambil $70 \%$ dari populasi, sehinggan sampel diperoleh sebanyak 42 orang Guru.

Penelitian ini menggunakan data primer, yang diperoleh melalui penelitian langsung terhadap obyek yang diteliti dengan cara melakukan interview kepada pihak-pihak yang terlibat dengan masalah yang sedang dibahas serta memberikan kuesioner kepada para guru yang sesuai dengan penelitian yang penulis lakukan. Untuk mendukung keakuratan dalam pengumpulan data ini, penulis melakukan dengan cara studi kepustakaan dan riset lapangan.

Dalam teknik analisis data, Sugiyono memberikan tahapan dalam melakukan teknik analisis data, yakni: 1) Mengelompokan data berdasarkan variabel dan jenis responden, 2) Mentabulasi data berdasarkan variabel dan seluruh responden, 3) Menyajikan data tiap variabel yang diteliti, 4) Melakukan perhitungan untuk menjawab rumusan masalah, 5) Melakukan perhitungan untuk menguji hipotesis yang telah diajukan. ${ }^{10}$

\section{Hasil dan Pembahasan}

\section{Teori Kepemimpinan Kepala Sekolah}

Kepemimpinan adalah sebuah proses dalam mengarahkan, membimbing, mempengaruhi, atau mengawasi

10 Arikunto, "Prosedur Penelitian: Suatu Pendekatan Praktis", (Jakarta: Rineka Cipta, 2010), h. 116 
pikiran, perasaan dan tindakan serta tingkah laku orang lain. Sedangkan menurut Robbins, Kepemimpinan adalah kemampuan mempengaruhi suatu kelompok ke arah pencapaian tujuan. Pengaruh itu dihasilkan dari interaksi atas dasar posisi formal ataupun informal. ${ }^{11}$

Edy Sutrisno mengatakan kepemimpinan adalah kemampuan seseorang dalam mempengaruhi orang lain, dimana bawahan akan melakukan apa yang menjadi kehendak pemimpin walaupun secara pribadi bawahan tersebut tidak menyukainya.12 Prajudi Atmosudirdjo juga mengemukakan yang dikutip Ngalim Purwanto, bahwa kepemimpinan dapat ditelaah dari berbagai segi: (a) Kepemimpinan dapat dirumuskan sebagai suatu kepribadian (personality) seseorang yang mendatangkan keinginan pada kelompok orangorang untuk mencontohnya atau mengikutinya, suatu kekuatan atau wibawa, yang demikian rupa sehingga membuat sekelompok orang-orang mau melakukan apa yang dikehendakinya, (b) Kepemimpinan dapat pula di pandang sebagai penyebab dari pada kegiatankegiatan, proses atau kesediaan untuk mengubah pandangan atau sikap (mental/fisik) dari pada kelompok orang-orang baik dalam hubungan organisasi formal dan informal, (c) Kepemimpinan adalah pula suatu seni

${ }^{11}$ Hadari Nawawi, Administrasi Pendidikan, NV. (Pontianak: Sapdodadi,1985) h. 79

12 Sudarwan Danin, Suparno, Manajemen (art), kesanggupan (ability) atau teknik (technique) untuk membuat sekelompok orang bawahan dalam organisasi formal atau para pengikut dalam organisasi informal mengikuti atau menaati segala apa yang dihendakinya, membuat mereka begitu bersemangat mengikutinya dan bahkan mungkin berkorban untuknya, (d) Kepemimpinan dapat pula dipandang sebagai suatu bentuk persuasi suatu seni pembinaan kelompok orangorang tertentu melalui "human relations" dan motivasi yang tepat sehingga tanpa rasa takut mau bekerja sama tulang untuk memahami dan mencapai segala yang menjadi tujuan organisasi. ${ }^{13}$

Kepemimpinan dapat pula dipandang sebagai suatu sarana, suatu instrumen atau alat, untuk membuat sekelompok orang-orang mau bekerja sama dan berdaya upaya menaati segala peraturan untuk mencapai tujuan-tujuan yang telah ditentukan. Bedasarkan pandangan beberapa ahli diatas dapat disimpulkan bahwa kepemimpinan adalah serangkaian dari kemampuan dan kepribadian seorang pemimpin sebagai alat untuk dapat mempengaruhi serta memotivasi orang-orang yang dipimpinnya agar mau bekerja sama dan mau melaksanakan segala tugas-tugas yang telah diberikan dengan sukarela, penuh semangat dan merasa tidak terpaksa. 


\section{Gaya Kepemimpinan}

Dalam kegiatan menggerakkan dan mengarahkan serta memotivasi orang lain agar bersedia melakukan tindakan yang dinginkan untuk pencapaian tujuan organisasi, berbagai cara dapat dilakukan oleh seorang pemimpin, Dan cara itu mencerminkan sikap serta pandangan seorang pemimpin yang memberikan gambaran dari bentuk kepemimpinan yang dijalankannya. ${ }^{14}$

Menurut Thoha, gaya kepemimpinan merupakan norma perilaku yang digunakan oleh seseorang pada saat orang tersebut mencoba mempengaruhi perilaku orang lain. Pada saat bagaimanapun jika seseorang berusaha untuk mempengaruhi perilaku orang lain maka ia telah melibatkan seseorang kedalam aktivitas kepemimpinan. 15

Gaya kepemimpinan kepala sekolah merupakan penentu berhasil atau mundurnya sekolah. Agar fungsi kepemimpinan kepala sekolah berhasil memberdayakan segala sumber daya sekolah untuk mencapai tujuan sesuai dengan situasi, diperlukan kemampuan profesional, yaitu kepribadian, keahlian dasar, pengalaman dan keterampilan profesional, pelatihan dan pengetahuan profesional, serta kompetensi administrasi dan pengawasan. Gaya kepemimpinan kepala sekolah merupakan implementasi dari kepemimpinan.

14 Burhanuddin, Analisis Administrasi Manajemen dn Kepemimpinan Pendidikan, (Jakarta: Bumi Aksara, 1994), h. 65

15 Thoha, Miftah, Kepemimpinan Dalam Manajemen, (Jakarta: PT Raja Grafindo Persada, 2009), h. 94
Menurut Hadari Nawawi Gaya kepemimpinan dibedakan menjadi tiga bentuk kepemimpinan, adapun diantaranya ialah:

1. Kepemimpinan otoriter

Kepemimpinan bentuk ini adalah menempatkan kekuasaan ditangan seseorang atau sekelompok kecil orang yang disebut atasan sebagai penguasa. ${ }^{16}$

Falsafah pemimpin, bawahan adalah untuk pemimpin (atasan) dan menganggap dirinya paling berkuasa, paling pintar dan mampu.

2. Kepemimpinan Laissez Faire

Bentuk kepemimpinan ini pemimpin melaksanakan kepemimpinannya dengan cara persuasif, menciptakan kerjasama yang serasi. pemimpin berkedudukan hanya sebagai simbol karena dalam realitas kepemimpinannya dilakukan dengan memberikan kebebasan sepenuhnya pada orang yang dipimpinnya. Pimpinan dalam menjalankan kepemimpinannya hanya berfungsi sebagai penasehat, dengan memberikan kesempatan kepada bawahan untuk bertanya jika merasa perlu. ${ }^{17}$

\section{Kepemimpinan Demokratis}

Bentuk kepemimpinan ini menempatkan manusia sebagai faktor utama dan terpenting, hubungan antara pemimpin dan bawahannya diwujudkan dalam bentuk Human Relationship yaitu didasari prinsip saling menghargai dan

${ }^{16}$ H. Malayu Hasibuan, Manajemen, Desain, Pengertian, dan Masalah, Jakarta: Rajawali,1990), h. 205

17 . Malayu Hasibuan, Manajemen, Desain, Pengertian, dan Masalah,207 
saling menghormati. Kepemimpinan demokratis ini adalah kepemimpina yang aktif, dinamis dan terarah yang berusaha memanfaatkan setiap orang untuk kemajuan bersama

Sedangkan menurut Sondang $P$. Siagian Gaya kepemimpinan terbagi dalam beberapa bentuk diantaranya ialah: otokratis, militeristis, paternalistis, karismatis, demokratis. ${ }^{18}$

\section{Pengertian Profesionalisme}

Profesionalitas berasal dari kata profesi (profession) yang dapat diartikan sebagai jenis pekerjaan yang khas atau pekerjaan yang memerlukan pengetahuan. Profesi dapat juga diartikan sebagai beberapa keahlian atau ilmu pengetahuan yang digunakan dalam aplikasi untuk berhubungan dengan orang lain, instansi atau sebuah lembaga. ${ }^{19}$

Dalam Undang Udanng Republik Indonesia No. 14 Tahun 2005 tentang guru dan dosen disebutkan dalam pasal 1 bahwa guru adalah pendidik professional dengan tugas utama mendidik, mengajar membimbing, mengarahkan, melatih, menilai peserta didik pada pendidika usia dini, jalur pendidikan formal, pendidikan dasar dan pendidikan menengah. ${ }^{20}$

Menurut Syaiful Bahri Djamarah, dalam proses belajar mengajar guru merupakan salah satu sumber belajar

18 Burhanuddin, Analisis Administrasi Manajemen dn Kepemimpinan Pendidikan, (Jakarta: Bumi Aksara, 1994), h. 90

19 H. Malayu Hasibuan, Manajemen, Desain, ₹ Pengertian, dan Masalah, Jakarta: Rajawali,1990), h 270 siswa yang memiliki peranan yang sangat penting dalam menentukan jalannya proses belajar mengajar. Tugas guru sebagai suatu profesi menuntut pada guru untuk mengembangkan profesionalitas diri sesuai dengan perkembangan ilmu pengetahuan dan teknologi. Mendidik, mengajar dan melatih anak didik adalah tugas guru sebagai profesi. Tugas guru sebagai pendidik berarti meneruskan dan mengembangkan nilainilai hidup kepada anak didik. ${ }^{21}$

Dalam mengajar seorang guru harus memiliki seperangkat kemampuan, baik dalam aspek kemampuan sikap maupun mendidik dan mengajarnya. Agar proses belajar mengajar berjalan efektif, maka guru harus lebih profesional dalam menjalankan tugasnya. Apabila guru tidak mempunyai profesionalitas dalam mengajar maka proses belajar mengajar tidak akan efektif, sehingga tujuan pendidikan secara umum tidak akan terwujud. Jadi guru yang profesional adalah guru yang mempunyai kemampuan dan keahlian khusus dalam melaksanakan kegiatan belajar mengajar sehingga mencapai sasaran berupa pencapaian tujuan-tujuan yang berkaitan dengan mata pelajaran yang disampaikan dan mempunyai kemampuan yang maksimal.

Menurut Abuddin Nata, profesionalisme adalah pandangan yang

20 Undang-undang R.I. No. 14 Tahun 2005, Tentang Guru dan Dosen, (Jakarta: Ciputat Press),

${ }^{21}$ Syaiful Bahri Djamarah dan Aswan Zain, Strategi Belajar Mengajar, (Jakarta: Rineka Cipta, 2000), h. 37 
menganggap bidang pekerjaan sebagai suatu pengabdian melalui keahlian tertentu dan menganggap keahlian sebagai sesuatu yang harus diperbarui secara terus menerus dengan memanfaatkan kemajuan- kemajuan yang terdapat dalam ilmu pengetahuan.

Penting bagi seorang guru untuk menguasai pengetahuan yang mendalam terkait bidang studinya masing-masing, bahkan pengetahuan lainnya yang berkorelasi dengan bidang studinya, agar mereka bisa menjawab pertanyaan dan memberikan pengetahuan yang luas bagi siswanya Jejen Musfah. ${ }^{22}$

Berdasarkan beberapa pendapat diatas dapat disimpulkan bahwa profsionalisme adalah pandangan yang menyatakan bahwa setiap pekerjaan harus dikerjakan oleh orang yang profesional. Guru yang profesional harus memiliki berbagai kemampuan dan keahlian khusus yang harus diperbaharui baik terkait dengan kepribadiannya, akhlak, spritual, pengetahuan dan keterampilannya sesuai dengan perkembangan ilmu pengetahuan. Jika guru sudah profesional maka kinerjanya pun akan baik karena sudah sesuai dengan kriteria guru yang baik.

\section{Pengertian Kinerja}

Kinerja merupakan sebuah pekerjaan yang dilakukan oleh seseorang yang sudah terencana untuk mencapai sebuah tujuan yang diinginkan. Kinerja

22 Abudin Nata, Pendidikan dalam Prespektif Hadis, (Jakarta: UIN Jakarta Press, 2005)h, 103

23 Kunandar, Guru Profesional:

Implementasi Kurikulum Tingkat Satuan merupakan salah satu aspek terpenting dalam sebuah organisasi. Kinerja menunjukkan sejauhmana kemampuan yang dimiliki karyawan dalam hal ini guru dalam bekerja. Seorang guru yang memiliki prestasi kerja yang bagus, maka guru cenderung dikatakan memiliki kinerja yang baik. kinerja adalah suatu tampilan secara utuh atas perusahaan selama periode waktu tertentu, merupakan hasil atau prestasi yang dipengaruhi oleh kegiatan operasional perusahaan dalam memanfaatkan sumber sumber daya yang dimiliki. ${ }^{23}$

Kinerja guru mempunyai spesifikasi / kriteria tertentu. Kinerja guru dapat dilihat dan diukur berdasarkan spesifikasi/kriteria kompetensi yang harus dimiliki oleh setiap guru. Seorang guru dalam kinerjanya harus bisa memberikan bekal pengetahuan secara kognitif, afektif dan psikomotor. Pengetahuan kognitif merupakan pengetahuan yang ditransformasikan oleh guru kepada siswanya, afektif yaitu pengetahuan sikap yang ditanamkan oleh guru dalam pendidikan, psikomotor berkenaan dengan keterampilan yang harus dikuasai oleh siswa dalam pembelajaran. Guru perlu mengetahui bahwa kinerjanya menekankan peserta didik pada kemampuan berkreasi,

Pendidikan (KTSP) dan Persiapan Menghadapi Sertifikasi Guru, (Jakarta: Raja Grafindo Persada, 2007), h. 47 
produktif, dan pelestarian nilai-nilai moral. ${ }^{24}$

Menurut hemat penulis bahwa yang dimaksud dengan kinerja guru itu merupakan kemampuan kerja seseorang guru yang ingin diperlihatkan dalam proses belajar mengajar agar tercapai tujuan pengajaran yang baik. Oleh karena itu guru di tuntut merencanakan pengajaran terhadap para siswa. agar guru mampu berperstasi dalam melaksanakan tugasnya serta mampu bertanggung jawab dalam melaksanakan tugas mendidik dan mengajar dengan baik, juga seorang guru yang profesional harus mempunyai kemampuan dasar atau kompetensi dan juga keterampilan dalam proses belajar mengajar. kinerja merupakan suatu wujud perilaku seseorang atau organisasi dengan orientasi prestasi.

\section{Pengaruh XI (gaya kepemimpinan), terhadap Y (Kinerja Guru)}

Koefesien korelasi antara gaya kepemimpinan dengan kinerja guru sebesar -093, dengan nilai signifikan 0,557. Artinya Ho diterima dan $\mathrm{Ha}$ ditolak. Artinya semakin baik gaya kepemimpinan semakin baik kinerja guru.

Berdasarkan hasil data di atas, maka dapat disimpulkan bahwa tidak terdapat pengaruh antara gaya kepemimpinan kepala sekolah terhadap kinerja guru di SMPN 1 Gondang. Hal tersebut dapat dibuktikan dengan nilai Signifikan 0,557 >
0,05 yang menandakan tidak terdapat pengaruh antara kedua variabel.

Kesimpulannya gaya kepemimpinan kepala sekolah SMPN 1 Gondang tidak mempengaruhi kinerja guru di SMPN 1 Gondang, karena: 1) model gaya kepemimpinan dari kepala SMPN 1 Gondang adalah kolektif, 2) di SMPN 1 Gondang terjadi pergantian kepala sekolah setiap tiga sampai empat tahun sekali, 3) kesadaran bekerja guru SMPN 1 Gondang terbangun atas dasar tanggung jawab terhadap negara, 4) kurangnya monitoring kepala sekolah terhadap pelaksanaan tugas guru.

\section{Pengaruh X2 (profesionalisme guru),} terhadap Y (Kinerja Guru)

Pada tabel di atas didapatkan koefesien korelasi antara profesionalisme guru dengan kinerja guru hanya sebesar -,102. Artinya Ho diterima dan Ha ditolak.

Berdasarkan hasil data di atas, maka dapat disimpulkan bahwa tidak terdapat pengaruh antara profesionalisme guru terhadap kinerja guru di SMPN 1 Gondang. Hal tersebut dapat dibuktikan dengan nilai Signifikan 0,552 > 0,05 yang menandakan bahwa tidak terdapat hubungan antara profesionalisme guru dengan kinerja guru di SMPN 1 Gondang.

Artinya profesionalisme guru tidak mempengaruhi kinerja guru di SMPN 1 Gondang, hal ini didasarkan pada instrumen yang peneliti buat, dimana

24 Syaiful Bahri Djamarah dan Aswan Zain, 
keberadaan instrumen ada kemungkinan kesalahan dalam pengisian yang dilakukan oleh guru. Dengan demikian penolakan hipotesis yang kedua didasarkan pada aspek metodologi yang memiliki tingkat margin error, dimana margin error ada pada setiap penelitian yang menggunakan metode kuantitatif.

\section{Pengaruh XI (gaya kepemimpinan) dan} $X 2$ (profesionalisme guru), terhadap $Y$ (Kinerja Guru)

$\mathrm{R}$ Square (koefesien determinasi) yang didapat sebesar 0,012 atau $1,2 \%$. Koefesien determinasi digunakan untuk mengetahui presentasi kontribusi variabel independen (bebas) terhadap perubahan variabel dependen (terikat), sedangkan besarnya kesalahan standar (Se) sebesar 5,47029. Artinya besarnya kontribusi variabel independen (bebas), yaitu gaya kepemimpinan dan profesionalisme guru terhadap perubahan variabel dependen (terikat) yaitu kinerja guru hanya $1,2 \%$, sedangkan sisanya 98,8\% disebabkan oleh variabel lain.

Angka korelasi antara X1 (gaya kepemimpinan kepala sekolah) dan X2 (profesionalisme guru) dengan $Y$ (kinerja guru) adalah 0,108. Karena angka korelasi tersebut berada di interval 0,000 - 0,199, maka hubungan antara X1 (gaya kepemimpinan kepala sekolah) dan X2 (profesionalisme guru) dengan Y (kinerja guru) di SMPN 1 Gondang dapat dikategorikan sebagai tingkat hubungan yang sangat rendah.

Tabel Anova di atas menunjukkan nilai $F_{\text {hitung sebesar }}=0,230$ dengan $\mathrm{df}_{1}=$ derajat kebebasan pembilang 2 dan $\mathrm{df}_{2}=$ derajat kebebasan penyebut 39, dengan tingkat signifikansi sebesar 0,796 >0,05, yang berarti Ha diterima dan Ho ditolak. Artinya terdapat hubungan yang signifikan antara tingkat gaya kepemimpinan dan profesionalisme guru dengan kinerja guru. Dengan demikian gaya kepemimpinan kepala sekolah dan profesionalisme guru mempengaruhi tingkat kinerja guru di SMPN 1 Gondang, namun sangat kecil yakni hanya 1,2\% saja.

Harga beta nol 63.072 (a), harga beta satu $\left(b_{1}\right)$ adalah 0.320 dan harga beta dua $\left(b_{2}\right)$ adalah -0.463 , maka persamaan garis regresi antara $X$ (gaya kepemimpinan kepala sekolah dan profesionalisme guru) dengan $Y$ (kinerja guru) dapat disusun sebagai berikut: $Y=63.072+0.320 . X_{1}+$ $0.463 . X_{2}$

Persamaan regresi yang telah ditemukan dapat digunakan untuk melakukan prediksi (estimasi) bagaimana kontribusi variabel independen terhadap besarnya perubahan variabel dependen. Misalnya gaya kepemimpinan sebesar 6, dan profesionalisme guru sebesar 5, maka kinerja gurunya adalah seperti persamaan dibawah ini:

Jadi estimasi kinerja guru sebesar 62.677 dengan gaya kepemimpinan sebesar 6 dan profesionalisme guru sebesar 5. Persamaan regresi di atas dapat diartikan bahwa nilai gaya kepemimpinan bertambah 1, maka nilai rata-rata kinerja guru akan bertambah 0.320, nilai profesionalisme guru 
bertambah 1, maka nilai rata-rata kinerja guru akan bertambah -0.463 .

Nilai $\mathrm{t}$ test $=0,433$, nilai ini digunakan dalam pengujian koefesien regresi untuk mengetahui apakah variabel independent (gaya kepemimpinan) berkontribusi secara signifikan terhadap perubahan nilai variabel dependent (kinerja guru). Dari tabel di atas didapat nilai signifikan sebesar 0,667 , artinya Ha diterima dan $\mathrm{Ho}$ ditolak. Artinya terdapat kontribusi signifikan antara gaya kepemimpinan terhadap kinerja guru.

Nilai $\mathrm{t}$ test $=-, 559$, nilai ini digunakan dalam pengujian koefesien regresi untuk mengetahui apakah variabel independent (profesionalisme guru) berkontribusi secara signifikan terhadap perubahan nilai variabel dependent (kinerja guru). Dari tabel di atas didapat nilai signifikan sebesar 0,579, artinya Ha ditolak dan Ho diterima. Artinya tidak terdapat kontribusi signifikan antara profesionalisme guru terhadap kinerja guru.

\section{Kesimpulan}

Berdasarkan hasil analisis data dan pembahasan, maka dapat ditarik kesimpulan bahwa:

Pertama, Terdapat pengaruh gaya kepemimpinan kepala sekolah terhadap profesionalisme guru di SMPN 1 Gondang. Pengaruh gaya kepemimpinan kepala sekolah dengan profesionalisme guru sebesar 98,3\%. Sehingga semakin baik gaya kepemimpinan kepala sekolah maka profesionalisme guru juga semakin baik. Kepemimpinan yang baik akan mempengaruh tingkat profesionalisme guru.

Kedua, Terdapat pengaruh gaya kepemimpinan kepala sekolah dan profesionalisme guru terhadap kinerja guru di SMPN 1 Gondang. Gaya kepemimpinan kepala sekolah SMPN 1 Gondang dan profesionalisme guru secara bersama-sama mempengaru kinerja guru di SMPN 1 Gondang. Namun pengaruh kedua variabel ini hanya 1,2\% dan sisanya 98,8\% dipengaruhi oleh faktor yang lain, artinya masih ada faktor atau variabel lain yang dapat mempengaruhi kinerja guru selain gaya kepemimpinan kepala sekolah dan profesionalisme guru, seperti faktor motivasi, kompetensi, budaya organisasi, iklim organisasi, disiplin kerja, etos kerja, dan lain-lain. 


\section{Daftar Pustaka}

Arifin, Mohammad. (2012). Kinerja Guru Profesional, Yogyakarta: Ar Ruzz Media

Arikunto, Suharsimi (2010), Prosedur Penelitian: Suatu Pendekatan Praktis, (Jakarta: Rineka Cipta, Edisi Revisi.

Burhanuddin (1994), Analisis Administrasi Manajemen $d n$ Kepemimpinan Pendidikan, Jakarta:Bumi Aksara

Danin, Suparno Sudarwan (2009), Manajemen dan Kepemimpinan Transformasional, Jakarta: Rineka Cipta

Djamarah, Syaiful Bahri dan Zain, Aswan (2000), Strategi Belajar Mengajar, Jakarta: Rineka Cipta

Hasibuan, H. Malayu (1990), Manajemen, Desain, Pengertian, dan Masalah, Jakarta: Rajawali

Jejen, Musfah (2011), Peningkatan Kompetensi Guru, Jakarta: Fajar Interpratama Mandiri

Kunandar (2007), Guru Profesional: Implementasi Kurikulum Tingkat Satuan Pendidikan (KTSP) dan Persiapan Menghadapi Sertifikasi Guru, Jakarta: Raja Grafindo Persada

Nata, Abudin (2005), Pendidikan dalam Prespektif Hadis, Jakarta: UIN Jakarta Press

Nawawi, Hadari (1985), Administrasi Pendidikan, Pontianak: NV. Sapdodadi
Nawawi, Hadari (2010), Administrasi Pendidikan, Jakarata: PT. Gunung Agung

Priansa, Donni Juni (2014), Kinerja dan Profesionalisme Guru, Bandung: CV. Alfabeta

Sedarmayanti dan Hidayat, S. (2011). Metodologi Penelitian. Bandung: CV Mandar Maju

Sedarmayanti. (2013). Manajemen Sumber Daya Manusia, Reformasi Birokrasi dan Manajemen pegawai negeri dan sipil. Bandung: Refika Aditama

Subagyo. (2013). Manajemen Pendidika. Semarang: FIS Universitas Semarang

Sugiyono. (2013). Metode Penelitian Pendidikan Pendekatan Kuantitatif, Kualitatif dan $R$ \& $D$. Bandung: Alfabeta

Sukmadinata, Nana Syaodih. (2010). Metode Penelitian Pendididkan. Bandung: PT Remaja Rosdakarya

Supardi. (2014). Kinerja Guru. (Jakarta: Raja Grafindo

Undang-undang R.I. No. 14 Tahun 2005(2006), Tentang Guru dan Dosen, Jakarta: Ciputat Press, cet. 1

Wahjosumidjo (2013), Kepemimpina Kepala Sekolah, Jakarta: Rineka Cipta 
Pengaruh Gaya Kepemimpinan Kepala Sekolah Dan

Profesionalisme Guru Terhadap Kinerja Guru Di SMP Negeri 1

Gondang Nganjuk

Oleh: Siti Arifatun Nasrifah \& Makhromi 